\title{
Radical Scavenging Activity of Kemenyan Resin Produced by an Indonesian Native Plant, Styrax sumatrana ${ }^{1}$
}

\author{
Asep Hidayat $^{2} \cdot$ Apri Heri Iswanto $\mathbb{D}^{3, \dagger} \cdot$ Arida Susilowati $^{4} \cdot$ Henti Hendalastuti Rachmat $^{2}$
}

\begin{abstract}
Kemenyan resin from Styrax sumatrana is a unique non-timber forest product (NTFP) native from Sumatera Island, Indonesia. It possesses a wide range of applications in the pharmaceutical, perfume, and cosmetics industries. In this paper, six kemenyan resin samples were investigated to evaluate their free radical scavenging activity using 1,1-diphenyl-2-picrylhydrazyl (DPPH) reagent. The kemenyan resin samples, which originated from North Tapanuli, Pakpak Bharat, and Humbang Hasundutan, showed high antioxidant activity with $\mathrm{IC}_{50}<16 \mathrm{mg} / \mathrm{L}$. The antioxidant activity of common kemenyan resin constituents, i.e., cinnamic acid, ethyl cinnamate, gallic acid, and vanillin was also investigated as positive control, although they exhibited lower antioxidant activity ( $\mathrm{IC}_{50}<1000 \mathrm{mg} / \mathrm{L}$ ), except for gallic acid $\left(\mathrm{IC}_{50}=5,23 \mathrm{mg} / \mathrm{L}\right.$ ). The total phenolic and flavonoid contents (TPC and TFC) for all samples were 44-66 mg gallic acid equivalents (GAE)/g sample and 143-160 mg quarcetin equivalents (QE)/g sample. The results revealed that kemenyan resin has high potency as an antioxidant and could be used as a natural antioxidant resource.
\end{abstract}

Keywords: Stryax sumatrana, kemenyan resin, antioxidant, total phenolic content, total flavonoid content

\section{INTRODUCTION}

Styrax sumatrana is one of the 130 tree species that belong to genus Styrax in Styracaceae. Among the genera of Styracaceae, Styrax stands out for the production of resinous material, commonly called as benzoid resin or kemenyan resin (Pauletti et al., 2006). Styrax sumatrana (S. sumatrana) is endemic from Indonesia and widely distributed in North of Sumatera. In 2012, S. sumatrana was cultivated in around 34,000 ha, and the largest area was located at Northern Tapanuli regency (Rahmawati, 2012). The production of kemenyan resin in Indonesia, mainly from six central areas, i.e., North Tapanuli, South Tapanuli, Humbang Hasundutan, Papak Bharat, Toba Samosir, and Dairi Regency - North Sumatera province, is about 4,000 ton/year (Silalahi et al., 2013). Previous studies about kemenyan resin from North Sumatera were conducted by Susilowati et al. (2017a,b), Rahmat et al. (2017), and Iswanto et al. (2016). Kemenyan resin is a non-timber forest product (NTFP) with high economical value for the local forest community. The price of resin

\footnotetext{
${ }^{1}$ Date Received May 24, 2018, Date Accepted July 3, 2018

${ }^{2}$ Forest Research and Development Centre, Research, Development and Innovation Agency, Ministry of Environment and Forestry Republic of Indonesia, Jl. Raya Gunung Batu No. 5, Bogor, 16001 Indonesia

${ }^{3}$ Department of Forest Product, Faculty of Forestry, Universitas Sumatera Utara, Padang Bulan, Medan 20155, Indonesia

${ }^{4}$ Department of Silviculture, Faculty of Forestry, Universitas Sumatera Utara, Padang Bulan, Medan 20155, Indonesia

$\dagger$ Corresponding author: Apri Heri Iswanto (e-mail: apriheri@yahoo.com, ORCID: 0000-0002-4243-1429)
} 
in global market depends on its quality, which is usually determined by factors such as size, color, odor, and fragility properties (Iswanto et al., 2015).

This resin has been widely used in many applications such as ritual ceremonies, perfumery, cosmetics, and medicinal fields (Hamm et al., 2004, Hovaneissian et al., 2008). Among its 130 compounds, the main ones are cinnamic acid, ethyl cinnamate, and vanillin. The resinous material of kemeyan resin from Indonesia is characterized by having a larger proportion of free cinnamic acid and cinnamate derivatives compared with other resins (Hovaneissian et al., 2008). Cinnamic acid derivatives bearing hydroxyl groups have been shown to exhibit strong free radical scavenging or antioxidants properties (Pontiki et al., 2014). In general, compounds having antioxidant activity are commonly added to foods and cosmetics as preservatives. The antioxidant activity is highly correlated with the content of phenolic/polyphenols, proteins/peptides, Vitamins C and $\mathrm{E}$, and also that of several metals (Sing et al., 2017). The hydroxyl groups of phenolic compounds play an important role in the antioxidant activity as scavengers of free radicals and reactive oxygen species (ROS), which are closely related with various diseases and the aging of skin tissues (Epstein, 2009; Park et al., 2004). Since kemenyan resin contains many saponin, lignin, triterpenes, and phenolic compounds (Pauletti et al., 2006), the investigation of its application as preservative, as well as a medicinal natural product, is of high interest.

The extracts from S. benzoin and S. formosanum have been previously evaluated, to find that they exhibit potential antioxidant activity (Teissedre and Waterhause., 2000; Hou et al., 2003). Moreover, other biological activities including anti-fungal, anti-bacterial, anti-inflammatory, and anti-cancer properties were studied (Pauletti et al., 2000; Kim et al., 2004a,b; Jung et al., 2003; Moon et al., 2005). In contrast, the plant and resinous extracts from S. sumatrana has been less studied. Therefore, the aim of this study was to investigate the phytochemical properties, and phenolic and flavonoid contents of kemenyan resin originated from North Sumatera, as well as the potential antioxidant activity of its main constituents, i.e., cinnamic acid, ethyl cinnamate, and vanillin.

\section{MATERIALS and METHODS}

\subsection{Sample collection}

Samples were collected at North Tapanuli regency, Pakpak Bharat regency, and Humbang Hasundutan regency, North Sumatra, Indonesia. All samples used in this study were kemenyan resin with class quality premium grade (I) and lowest grade (II). Kemenyan resin was diluted with methanol $99 \%$ solvent, and the solution was stored in refrigerator prior to use.

\subsection{Chemicals}

1,1-Diphenyl-2-picrylhydrazyl (DPPH) was purchased from Sigma Chemicals. Cinnamic acid was purchased from Aldrich Chemicals. Vanillin, gallic acid, ethyl cinnamate, and sodium carbonate were purchased from Himedia Chemicals. Folin-Ciocalteu (FC) reagent was purchased from Merck Chemicals. All other chemicals were prepared with analytic grade.

\subsection{Procedures}

\subsubsection{Phytochemical assay}

The phytochemical assay was carried out according to the methods described by Tapwal et al. (2016) with slight modifications. In particular, phenolic and tannin were evaluated by ferric chloride test, flavonoid was evaluated by addition of magnesium and hydrochloric acid, steroid was evaluated by a mixture of acetate anhydrate and sulfuric acid, terpenoid was evaluated by addition of sulfuric acid, and alkaloid was evaluated 

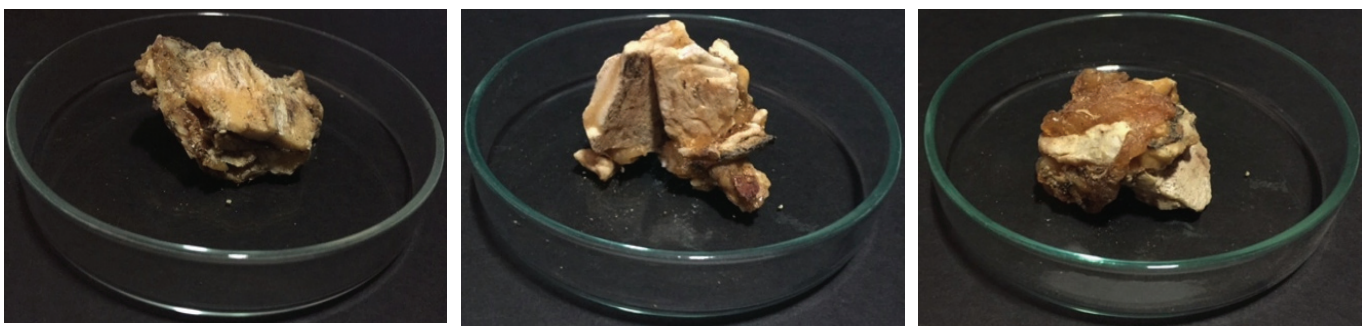

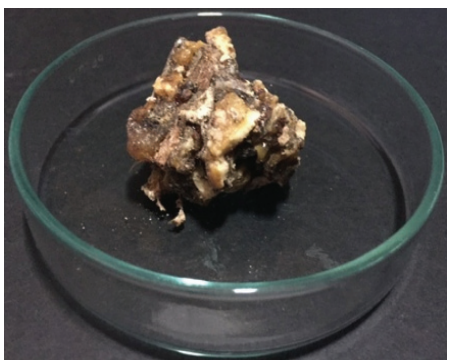

A

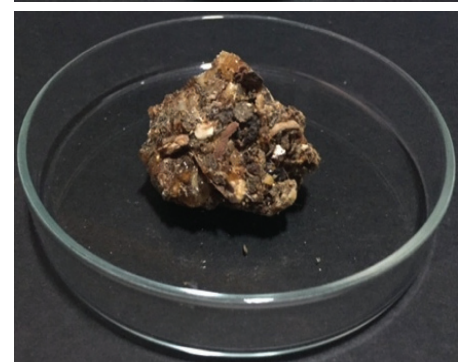

B

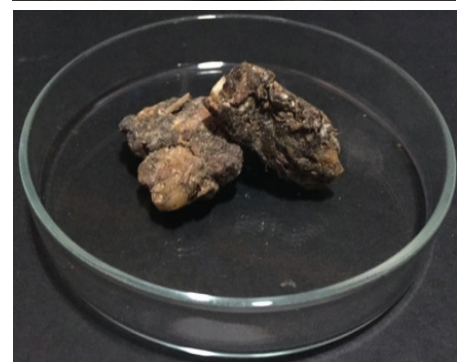

C

Fig. 1. Kemenyan resin samples collected from Pakpak Bharat (A), North Tapanuli (B), and Humbang Hasundutan (C) with class quality premium grade (I) and lowest grade (II).

by using Mayer's and Wagner's reagents.

\subsubsection{Phenolic content}

Evaluation of the total phenolic content (TPC) was performed following a modification of a previously described method (Tambe and Bhambar, 2014). The kemenyan resin solution was used in a final concentration of $40 \mathrm{mg} / \mathrm{mL}$. Gallic acid was used as a standard, and the corresponding concentrations were prepared in the range of 0.8 to $4 \mathrm{mg} / \mathrm{mL}$ at the final reaction. Each kemenyan resin, standard solution, or methanol as a blank was added to a solution of 0.25 $\mathrm{mL}$ of $\mathrm{FC}$ reagent in $1.4 \mathrm{~mL}$ aquadest. After $8 \mathrm{~min}$ incubation, $0,75 \mathrm{~mL}$ of sodium carbonate (7.5\%) was added to the mixture, and its absorbance at $715 \mathrm{~nm}$ was recorded after $2 \mathrm{~h}$ incubation. TPC was calculated by plotting the absorbance value in the standard calibration curve of gallic acid. All the tests were conducted in triplicate. The content of total phenol was expressed as mg of gallic acid equivalents (GAE) per $\mathrm{g}$ of kemenyan resin.

\subsubsection{Flavonoid content}

Evaluation of the total flavonoid content (TFC) was carried out according to a modification of a previously described colorimetric method (Tambe and Bhambar, 2014). The kemenyan resin solution was used in the final concentration of $20 \mathrm{mg} / \mathrm{mL}$. Quarcetin was used as a standard, and the corresponding concentrations were prepared in the range of 1 to $20 \mathrm{mg} / \mathrm{mL}$ at the final reaction. Each kemenyan resin, standard solution, or methanol as a blank was added to a $0.15 \mathrm{~mL}$ solution of $\mathrm{NaNO}_{3}$ (5\%) in $2.6 \mathrm{~mL}$ aquadest and incubated for 8 min. Then, $0,15 \mathrm{~mL}$ of $\mathrm{FeCl}_{3}$ (10\%) was added, and the resulting mixture was further incubated for $6 \mathrm{~min}$. A solution of $\mathrm{NaOH}(1 \mathrm{~N})$ was added to obtain a reaction volume of $5 \mathrm{~mL}$, and the absorbance of this mixture at $510 \mathrm{~nm}$ was recorded after $30 \mathrm{~h}$ incubation. TFC was calculated by plotting the absorbance value in the standard calibration curve of quarcetin. All the tests were conducted in triplicate. The content of total flavonoid was expressed as mg of quarcetin equivalents (QE) per $g$ of kemenyan resin. 


\subsubsection{Antioxidant assay}

The antioxidant activity of kemenyan resin for DPPH free radical was determined according to a previous method (Kuspradini et al., 2016) with slight modifications. In a series of test tubes, kemenyan resin, cinnamic acid, ethyl cinnamate, and vanillin solutions were diluted with methanol affording concentrations in the range of 10 to $100 \mathrm{mg} / \mathrm{L}$, and $0.25 \mathrm{~mL}$ of a DPPH (1 M) solution was added to obtain a final reaction volume of $2.5 \mathrm{~mL}$. After $30 \mathrm{~min}$ incubation at room temperature, the absorbance was monitored at $517 \mathrm{~nm}$. The methanolic solution without sample and gallic acid was selected as blank and positive controls, respectively. All the tests were conducted in triplicate. The inhibitory effect of DPPH was calculated using to the following formula:

\section{Scavenging activity (\%) \\ $=[$ absorbance of the control - absorbance of the sample) / absorbance of the control] $x$ $100 \%$}

The antioxidant activity was expressed as $\mathrm{IC}_{50}$, which refers to the amount of sample necessary to reduce the initial DPPH concentration by half.

\subsubsection{Toxicity assay}

The brine shrimp lethality test (BSLT) method was used to investigate the toxicity activity, according to the method described by Mirzaei et al. (2013). The kemenyan resin was added in gradient concentrations to a vial containing $4.5 \mathrm{~mL}$ of the brine shrimp solution. Ten brine larvae developed for $48 \mathrm{~h}$ were then added to the vial. The control solution was prepared with methanol, Tween80, and seawater. The vial was incubated in the darkness at room temperature for 24 h. Feeding and air were not allowed during the experiment. After $24 \mathrm{~h}$, the number of dead shrimps was counted, and the toxicity of the sample was determined. The percentage of mortality was calculated and analyzed using the probit value method. The toxicity activity was expressed as $\mathrm{LC}_{50}$, which indicates the amount of sample necessary to reduce ten brine shrimp larvae by half.

\section{RESULTS and DISCUSSION}

\subsection{Solubility of kemenyan resin}

A preliminary study was conducted to assess the solubility of kemenyan resin in three different solvents, namely methanol, ethanol, and ethyl acetate. Methanol provided the best result (data not shown), which was expected considering that kemenyan resin is mainly constituted by polar compounds (Kiswandono et al., 2016). Therefore, methanol was selected as the solvent for this study.

\subsection{Phytochemical assay}

The qualitative result of the phytochemical assay showed that all the samples contained phenolic, flavonoid, tannin, and terpenoid compounds (Table 1). Total phenolic and flavonoid contents were investigated by using the Folin-Ciocalteu method and $\mathrm{AlCl} 3$ as reactant. The results are presented in Table 1.

The measurement of the TPC and TFC values showed that all kemenyan samples tested contained similar amounts of phenolic and flavonoid compounds (44.75-66.41 mg GAE/g and 143.23-160.89 mg QE/g, respectively). Tannins and terpenoids were also present in all the samples, whereas steroids and alkaloids were absent. Phenolic and polyphenol compounds, which originate from secondary metabolites, have one or more hydroxyl groups located in the benzene ring, and their scavenging properties for free radicals are well known (Evans et al., 1997; Halliwell and Gutteridge, 2006). Free radicals are key intermediates in diseases such 
Asep Hidayat $\cdot$ Apri Heri Iswanto $\cdot$ Arida Susilowati $\cdot$ Henti Hendalastuti Rachmat

Table 1. Phytochemical assay of kemenyan resin from some locations in North Sumatera Province

\begin{tabular}{|c|c|c|c|c|c|c|c|c|c|c|c|}
\hline \multirow{2}{*}{ No } & \multirow{2}{*}{ Origin } & \multirow{2}{*}{ Class } & \multicolumn{3}{|c|}{ Phenolic } & \multicolumn{2}{|r|}{ Flavonoid } & \multirow{2}{*}{ Tannin } & \multirow{2}{*}{ Terpenoid } & \multirow{2}{*}{ Steroid } & \multirow{2}{*}{ Alkaloid } \\
\hline & & & A & & B* & A & $\mathrm{B}^{* *}$ & & & & \\
\hline \multirow{2}{*}{1} & \multirow{2}{*}{ Pakpak Bhara } & $\mathrm{I}$ & + & 52.42 & \pm 0.48 & + & $160.23 \pm 12.39$ & + & + & - & - \\
\hline & & II & + & 56.37 & \pm 0.27 & + & $153.96 \pm 11.42$ & + & + & - & - \\
\hline \multirow{2}{*}{2} & \multirow{2}{*}{ North Tapanuli } & I & + & 44.75 & \pm 6.42 & + & $143.23 \pm 18.46$ & + & + & - & - \\
\hline & & II & + & 66.41 & \pm 10.92 & + & $156.11 \pm 4.60$ & + & + & - & - \\
\hline \multirow{2}{*}{3} & \multirow{2}{*}{ Humbang Hasundutan } & $\mathrm{I}$ & + & 47.72 & \pm 9.82 & + & $159.41 \pm 14.12$ & + & + & - & - \\
\hline & & II & + & 58.81 & \pm 2.29 & + & $160.89 \pm 13.67$ & + & + & - & - \\
\hline
\end{tabular}

Note: $\mathrm{A}=$ qualitative test, $\mathrm{B}=$ quantitative test, $*=\mathrm{mg} \mathrm{GAE} / \mathrm{g}$ sample, $* *=\mathrm{mg} \mathrm{QE} / \mathrm{g}$ sample, $+=$ detected, $-=$ not detected

as diabetes mellitus, cancer, liver diseases, renal failure, and degenerative diseases (Silva et al., 2016).

\subsection{Antioxidant and toxicity assay}

The radical scavenging and antioxidant activity of kemenyan resin was evaluated by the DPPH assay due to its low cost, easiness, and widespread use (Apak et al., 2016, Kim et al., 2010; Lee et al., 2004, Park et al., 2004; Park et al., 2012; Hou et al., 2003; Kim et al., 2014). The antioxidant activities ( $\left.\mathrm{IC}_{50}\right)$ for all the samples were found to lie in the range 15.28-31.74 $\mathrm{mg} / \mathrm{L}$ (Table 2). The $\mathrm{IC}_{50}$ value of first class kemenyan resin was higher (15.28-16.50 $\mathrm{mg} / \mathrm{L})$ than second class kemenyan resin (21.12-31.74 $\mathrm{mg} / \mathrm{L})$. This result indicates that kemenyan resin has high capacity of inhibition of free radical molecules of DPPH. Kemenyan resin with higher grade (first class) originated from all sites showed higher inhibition activities compared with those of lower grade quality (second class) (Table 2). Furthermore, the standard samples used as positive control, i.e., vanillin, cinnamic acid, and ethyl cinnamate (Pauletti et al., 2006), showed no inhibition activity of free radical molecules. Meanwhile, gallic acid showed stronger activity than butylated hydroxytoluene, which were also tested as positive controls. Gallic acid is commonly used as positive control in antioxidant assays
(Sharma and Vig, 2013; Kim et al., 2014; Noreen et al., 2017), since its three -OH molecules render it very active compared with other constituents (Karamac et al., 2005). Pauletti et al. (2006) reported that Styrax Genus is composed of 30 phenolic compounds related to benzoic and cinnamic acids. The difference in the antioxidant activity has been reported to depend on the capacity of polyphenol compounds for stabilizing the DPPH free radical molecules (Karamac et al., 2005). When comparing kemenyan resin of first and second class, this difference is also related to the purity, quality, and the quantity of constituents. In this context, it is worth noting that first class kemenyan resin has a clearer appearance than second class kemenyan resin (Fig. 1).

A linear relationship between total phenolic content, total flavonoid content, and antioxidant activity of kemenyan resin was also observed. The total phenolic content showed higher relationship $(r=0.6)$ than the total flavonoid acid content $(r=0.3)$, which is indicative of phenolic compounds playing an important role in the antioxidant activity with the donation of one or more hydroxyl groups. Experimentally, this could be observed in the change of DPPH color from purple to yellow. Previous studies reported that the total phenolic content has a strong positive correlation with the antioxidant capacity (Sadeghi et al., 2015). Due to the redox property of phenolic compounds, they can 
Radical Scavenging Activity of Kemenyan Resin Produced by an Indonesian Native Plant, Styrax sumatrana

Table 2. The antioxidant and toxicity activity of kemenyan resin and standard compounds

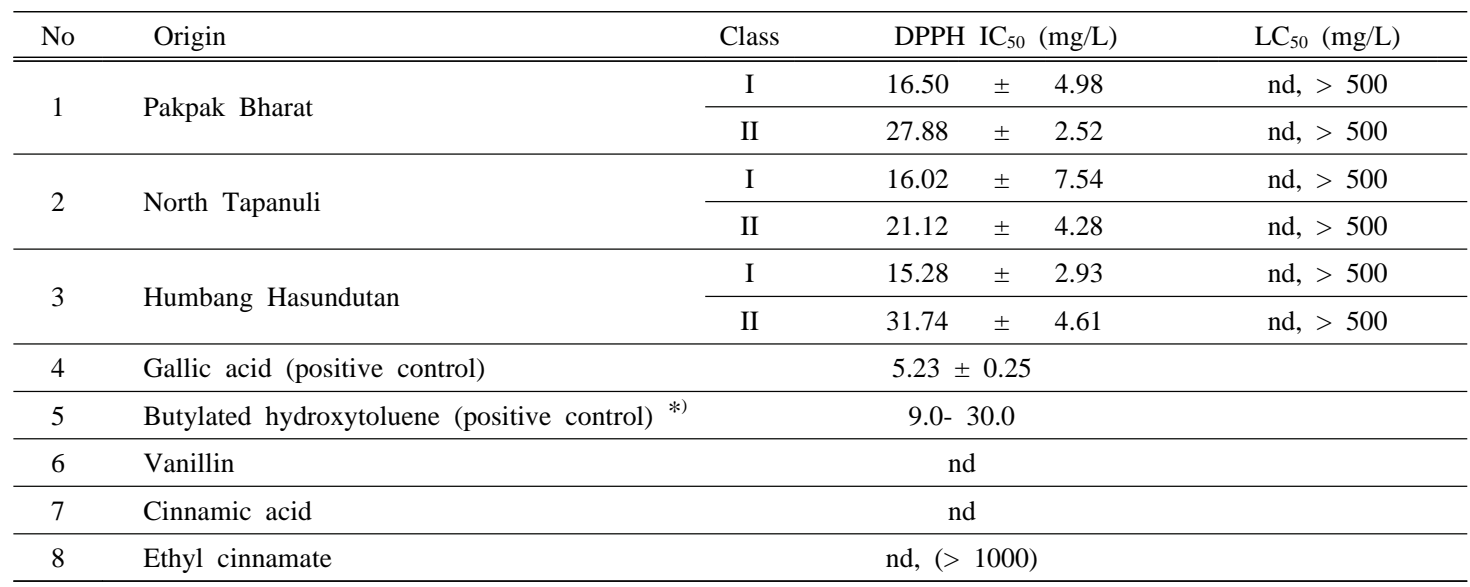

Note: nd= not detected; ${ }^{*)}$ Kim et al. (2010) and Lee et al. (2004).

act as potent reducing agents, hydrogen donors, and singlet oxygen quenchers, leading to the antioxidant activity (Khoddami et al., 2013; Yashin et al., 2017). Flavonoids have higher antioxidant activities (Yashin et al., 2017), but their antioxidant activity strongly depends on their chemical structure, which is particularly influenced by the number and position of hydroxyl groups attached to the two aromatic rings (Promden et al., 2014; Park et al., 2004). A BLST test (Table 2) showed that all samples have $\mathrm{LC}_{50}$ values above $500 \mathrm{mg} / \mathrm{L}$, which is indicative of a low toxicity according to the value reported by McLaughlin and Rogers, 1998 ( $\mathrm{LC}_{50}>200$ mg/L). Furthermore, increasing the concentration of kemenyan resin up to a level $<500 \mathrm{mg} / \mathrm{L}$ still resulted in low mortality rate $(<50 \%)$. This experiment determined that all samples exhibited $\mathrm{LC}_{50}$ values above $500 \mathrm{mg} / \mathrm{L}$, which renders kemenyan resin originated from North Sumatera a potential candidate as antioxidant bioactive compound.

\section{CONCLUSION}

In this study, we investigated the bioactive properties of six kemenyan resin samples from North Tapanuli,
Pakpak Bharat, and Humbang Hasundutan - North Sumatera Province. All samples contained phenolic and flavonoid compounds, which can serve as natural sources of free radical scavengers. The antioxidant activities of the samples were in the range 15.28- 31.74 $\mathrm{mg} / \mathrm{L}$, in which the phenolic compounds play an important role with the donation of one or more hydroxyl groups. Antioxidant compounds can protect against the negative effect of many physiological and pathological processes; however, the antioxidant activity of Kemenyan resin in Indonesia has been scarcely studied. According to our results, kemenyan resin has prospective value as a natural antioxidant resource.

\section{ACKNOWLEDGMENT}

We would like to express my sincerely thanks to SEAMEO BIOTROP for funding support through to the Joint Research Grant year 2017 (Number: 052.11/ PSRP/SC/SPK-PNLT/III/2017 date: March 15, 2017).

\section{REFERENCES}

Apak, R., Özyürek, M., Güçlü, K., Çapanoğlu, E. 2016. 
Asep Hidayat $\cdot$ Apri Heri Iswanto $\cdot$ Arida Susilowati $\cdot$ Henti Hendalastuti Rachmat

Antioxidant Activity/Capacity Measurement. 2. Hydrogen Atom Transfer (HAT)-Based, MixedMode (Electron Transfer (ET)/HAT), and Lipid Peroxidation Assays. Journal of Agricultural and Food Chemistry 64(5): 1028-1045.

Epstein, H. 2009. Cosmeceuticals and polyphenols. Clinic and. Dermatology 27(5): 475-488.

Evans, C.R., Miller, N., Paganga, G. 1997. Antioxidant properties of phenolic compounds. Trends in Plant Science 2(4): 152-159.

Halliwell, B., Gutteridge, J.M. C. 2006. Free radicals in biology and medicine. Oxford: Clarendon Press.

Hamm, S., Bleton, J., Tchapla, A. 2004. Headspace solid phase microextraction for screening for the presence of resins in Egyptian archaeological samples. Journal of Separation Science 27(3): 235-243.

Hou, W.C., Lin, R.D., Cheng, K.T., Hung, Y.T., Cho, C.H., Chen, C.H., Hwang, S.Y., Lee, M.H. 2003. Free radical-scavenging activity of Taiwanese native plants. Phytomedicine 10(2-3): 170-175.

Hovaneissian, M., Archier, P., Mathe, C., Culioli, G., Vieillescazes, C. 2008. Analytical investigation of Styrax and benzoin balsams by HPLC-PADfluorimetry and GC-MS. Phytochemical Analysis 19(4): 301-310.

Iswanto, A.H., Susilowati, A., Azhar I, Riswan., Supriyanto., Tarigan, J.E., Fatriasari W. 2016. Physical and Mechanical Properties of Local Styrax Woods from North Tapanuli in Indonesia. Journal of the Korean Wood Science and Technology 44(4): 539-550.

Iswanto, A.H., Susilowati, A., Azhar, I., Riswan., Supriyanto. 2015. Technical and Economical Study of Kemenyan (Styrax sp) From North Sumatera to Support Kemenyan Market Sustainability. Final Report DIPA Seameo Biotrop, Bogor, Indonesia. Jung, H., Moon, T.C., Lee, E., Son, K.H., Kim, H.P., Kang, S.S., Bae, K.H., An, R.B., Kwon, D.Y.,
Chang, H.W. 2003. Screening of arachidonic acid cascade related enzyme inhibitors from Korean indigenous Plants (1). Yakhak Hoechi 47: 69-77.

Karamac, M., Kosiñska, A., Pegg, R.B., 2005. Comparison Of Radical-Scavenging Activities For Selected Phenolic Acids. Polish Journal of Food and Nutrition Sciences 14(55): 165-170.

Khoddami, A., Wilkes, M.A., Roberts, T.H. 2013. Techniques for Analysis of Plant Phenolic Compounds. Molecules 18: 2328-2375.

Kim, J.S., Lee, H.C., Jo, J.S., Jung, J.Y., Ha, Y.L., Yang, J.K. 2014. Evaluation of Antioxidant and Anticancer Activity of Steam Extrcat from The Bamboo Species. Journal of the Korean Wood Science and Tenology 42(5): 543-554.

Kim, J.Y., Kwon, D.J., Lim, S.S., Bae, Y.S. 2010. Antioxidant and Anti-inflammatory Activity of Stem Bark Extracts from Ulmus davidiana var japonica. Journal of the Korean Wood Science and Tenology 38(5): 444-449.

Kim, M.R., Lee, H.H., Hahm, K.S., Moon, Y.H., Woo, E.R. 2004a. Pentacyclic triterpenoids and their cytotoxicity from the stem bark of Styrax japonica S. et Z. Archive of Pharmacal Research 27(3): 283-286.

Kim, Y.S., Oh, B.C., Shin, D.H. 2004b. The extension of the shelf life of cooked rice by the treatment with the plant extracts and their volatile constituents. Food Science and Biotechnology 13(4): 519-522.

Kiswandono, A.A., Iswanto, A.H., Susilowati, A., Lumbantobing, A.F. 2016. Analysis of The Content of Cinnamic Acid and Phytochemical Screening Sap Incense Type of Bulu (Styrax Benzoine Var. Hiliferum) of North Tapanuli. Proc of Chemical National Seminary 2016. Mataram, Agustus 10-11, 2016. Article No. B.016: 146-155. [Indonesia].

Kuspradini, H., Rosiarto, M.A., Putri, A.S., Kusuma, I.R. 2016. Antioxidant and toxicity properties of 
Radical Scavenging Activity of Kemenyan Resin Produced by an Indonesian Native Plant, Styrax sumatrana

anthocyanin extracted from red flower of four tropical shrubs. Nusantara Bioscience 8(3): 135-140.

Lee, Y.S., Lee, H.J., Park, Y., Park, J.I., Choi, T.H. 2004. Antioxidative constituents from the Wood of Liriodendron tulipifera. Journal of the Korean Wood Science and Tenology 32(6): 43-49.

McLaughlin, J.L., Rogers, L.L. 1998. The use of biological assays to evaluate botanicals. Drug Information Journal 32: 513-524.

Mirzaei, A., Mirzaei, N., Ghavamizadeh, M. 2013. Antioxidant Activity and Cytotoxicity of Dorema aucheri by Artemia urmiana: a Brine Shrimp Lethality Test. Journal of Life Sciences 10(12s): 8-12.

Moon, H.I., Kim, M.R., Woo, E.R., Chung, J.H. 2005. Triterpenoid from Styrax japonica Sieb. et Zucc, and its effects on the expression of matrix metalloproteinases- 1 and type 1 procollagen caused by ultraviolet irradiated cultured primary human skin fibroblasts. Biological and Pharmaceutical Bullettin 28(10): 2003-2006.

Noreen, H., Semmar, N., Farman, M., McCullagh, J.S.O. 2017. Measurement of total phenolic content and antioxidant activity of aerial parts of medicinal plant Coronopus didymus. Asian Pasific Journal of Tropical Medicina 10(8): 792-801.

Park, S.Y., Bae, Y,S. 2012. Antioxidative Activity of Prunus sargentii Outer Bark Extractives. Journal of the Korean Wood Science and Tenology 40(2): 141-146.

Park, Y., Choi, D.H., Lee, H.J., Lee, S.S., Lee, W.Y., Ahn, J.K. 2004. Structure-antioxidant activity Relationships of Isoflavonoids. Journal of the Korean Wood Science and Tenology 32(3): 66-70. Pauletti, P.M., Araújo, A.R., Young, M.C.M, Giesbrecht, A.M., Bolzani, V.S. 2000. Nor-Lignans from the leaves of Styrax ferrugineus (Styracaceae) with antibacterial and antifungal activity. Phytochemistry 55(6): 597-601.
Pauletti, P.M., Teles, H.L., Silva, D.H.S., Araújo, A.R., Bolzani, V.S. 2006. The Styracaceae. Brazilian Journal of Pharmacognosy 16(4): 576-590.

Promden, W., Monthakantirat, O., Umehara, K., Noguchi, H., De-Eknamkul, W. 2014. Structure and Antioxidant Activity Relationships of Isoflavonoids from Dalbergia parviflora. Molecules 19: 22262237.

Rahmat, H.H., Susilowati, A., Kholibrina, C.R., Noni, W. 2017. Strong genetic differentiation of the endemic rosin-producing tree Styrax sumatrana (Styracaceae) in North Sumatra, Indonesia. Biodiversitas 18(4): 1331-1335.

Rahmawati, D. 2012. Aktivitas antiinflamasi senyawa asam sinamat dari kemenyan pada tikus galur wistas. [skripsi]. Institut Pertanian Bogor, Bogor. [Indonesian].

Sadeghi, Z., Valizadeh, J., Shermeh, O.A., Akaberi, M. 2015. Antioxidant activity and total phenolic content of Boerhavia elegans (choisy) grown in Baluchistan, Iran. Avicenna Journal of Phytomedicina 5(1): 1-9.

Sharma S., Vig, P.A. 2013. Evaluation of In Vitro Antioxidant Properties of Methanol and Aqueous Extracts of Parkinsonia aculeata L. Leaves. The Scientific World Journal 2013: ID 604865.

Silalahi, J., Sukmana, A., Antoko, B.S., Sunandar, A.D., Barus, J.A., Manik, W.S., Sanjaya, H. 2013. Buku Kecil: Kemenyan Getah Berharga Tano Batak. Balai Penelitian Kehutanan Aek Nauli. Parapat. Sumatera Utara. [Indonesian].

Silva, T.A., Polo, E.M., Henrique, C.Y., Alves, O.J.A., Nicolella, H.D., Gimenez, V.M.M., Araújo, A.R.B., Tavares, D.C., e Silva, M.L.A., Cunha, W.R., Januário, A.H., Pauletti, P.M. 2016. Styrax camporum and $S$. ferrugineus fruits: norneolignans, antioxidant and cytotoxic activities. Journal of Applied Pharmaceutical Science 6(11): 075-080. Singh, M., Seth, P., Poddar, S. 2017. Comparative 
Asep Hidayat - Apri Heri Iswanto • Arida Susilowati - Henti Hendalastuti Rachmat

Analysis of Four Facial Foundation Lotions with Reference to Its Antioxidant Richness and BioSafety. Cosmetics 4(2): 1-9.

Susilowati, A., Elfiati, D., Hartini, K.S., Rahmat, H.H., Ramadhani, R. 2017a. Weak Delineation of Styrax Species Growing in North Sumatra-Indonesia by matK+rbcLGene. Biodiversitas 18(3): 1270-1274.

Susilowati, A., Hartini, K.S., Rahmat, H.H., Alvarobi, M. 2017b. Propagation of Valuable North Sumatera Benzoin (Styrax spp) Using Macrocutting Technique. IOP Conference Series: Materials Science and Engineering 180: 012046.

Tambe, V.D., Bhambar, R.S. 2014. Estimation of total phenol, tannin, alkaloid and flavonoid in Hibiscus tiliaceus Linn. Wood extract. Research and Reviews: Journal of Pharmacognosy and Phytochemistry
2(4): 41-47.

Tapwal, A., Pradhan, S., Chandra, S., Rashmi. 2016. Short Communication: Antimycotic activity and phytochemical screening of fungal endophytes associated with Santalum album. Nusantara Bioscience 8(1): 14-17.

Teissedre, P.L., Waterhouse, A.L. 2000. Inhibition of oxidation of human low-density lipoproteins by phenolic substances in different essential oils varieties. Journal of Agricultural Food and Chemistry 48(9): 3801-3805.

Yashin, A., Yashin, Y., Xia, X., Nemzer, B. 2017. Antioxidant Activity of Spices and Their Impact on Human Health: A Review. Antioxidants 6(3): 2-18. 